Factors that motivate Turkish EFL teachers

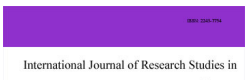

Language Learning volume 1 Number 1 lamuary 2012

Erkaya, Odiléa Rocha

Eskisehir Osmangazi University, Turkey (opre_br@yahoo.com)

\title{
Abstract
}

Teachers' motivation has been an extensive topic of discussion among researchers for over two decades. What has been missing in the discussion, though, is the perspective of those who teach English as a Foreign Language (EFL), especially those who work in Turkey. Therefore, the purpose of this case study was to investigate factors that motivated Turkish EFL teachers working at a Preparatory English Program of a university in Turkey and ways to enhance their motivation. Eight teachers took part in the study. To collect data, unstructured interviews were used. Then, codes were written and themes on teachers' motivation and demotivation, and ways to motivate teachers emerged. The results can be understood by looking at expectancy theory, more specifically on the focus of the theory: intrinsic (personal) and extrinsic (environmental) motives. The analysis of what the teachers believed to be their source of motivation and demotivation helped the researcher to propose ways to enhance their motivation.

Keywords: motivation; demotivation; intrinsic and extrinsic motives; expectancy theory; enhancement of teachers' motivation 


\section{Factors that motivate Turkish EFL teachers}

\section{Introduction}

Human beings in general feel enthusiastic performing tasks or complete tasks successfully when they are motivated. In reference to teachers, their motivation is imperative since students' motivation appears to be directly correlated with teachers' motivation. One may wonder the origin of teachers' motivation. It may be a result of intrinsic or extrinsic factors, or both. What is amazing is that most teachers are intrinsically motivated when they become teachers, but along the years they may lose motivation and some may become so demotivated that they may even change profession. As a result, administrators should do whatever they can to help teachers stay motivated or become even more motivated throughout the years. And, the reason is that "when teachers are provided with what they need to remain inspired and enthusiastic in the classroom, students as well as teachers will be the beneficiaries" (Lumsden, 1998, p. 5).

Overall, what has happened regarding teachers' motivation is that much has been written since the 1990s (Bishay, 1996; Czubaj, 1996; Pinto \& Pulido, 1997; Scott, Cox, \& Dinham, 1999; Scott \& Dinham, 1999; What makes teachers tick?, 2002; Su, 2012; just to name a few). Nevertheless, few articles have been written about English as a Second Language (ESL) and English as a Foreign Language (EFL) teachers' motivation. An article that called the researcher's attention to the lack of investigations in ESL and EFL was Dörnyei's (2003). In his article, Dörnyei (2003) confirmed how "meager" and "overlooked" research on ESL/EFL teachers' motivation had been. Consequently, this area had become "attractive". Dörnyei cited researchers who had laid the foundations for teachers' motivation such as Doyle and Kim (1999), Dörnyei (2001), Jacques (2001), Kassabgy, Boraie, and Schmidt (2001), Pennington (1992 and 1995), and Pennington and Ho (1995). However, Dörnyei (2003) stated that no researchers had compiled a list of "ways to motivate language teachers, even though a scientifically validated list of this sort would predictably be very useful and much sought after" (p. 26).

Thus far, no research on Turkish EFL teachers' motivation has been conducted. Hence, using the Turkish EFL context, the researcher has tried to find out what motivates Turkish EFL teachers working at a Preparatory English Program and how their motivation can be enhanced. The study addresses the following questions:

A. What motivates Turkish EFL teachers working at a Preparatory English Program of a university in Turkey?

B. How can the Turkish teachers' motivation be enhanced?

This case study has been an effort to shed light on factors that motivate Turkish EFL teachers and on ways to improve their motivation, with the idea that such research might be applied to other Turkish EFL teachers, especially to those teaching in preparatory English programs, in spite of the small number of participants taking part in the study.

\section{Literature Review}

\subsection{Theory of motivation}

Motivation theorists have tried to discover why human beings are motivated to perform tasks without being told to do so. Theorists understand how hard it is for anybody to motivate people due to people's complexities and differences, and for anyone to motivate himself/herself. What motivates EFL teachers is what the researcher proposes to find out in the present study. To assist with the data analysis, several of the motivation theories were considered; conversely, the researcher took into account what had been said about the theories that could help a 
researcher to understand teachers' motivation. Dörnyei (2001), for example, affirmed: "Scholars have argued that teacher motivation can be best understood in the light of... expectancy theory..." (p. 157) and other theories. Johnson (1986) also listed some theories that could assist in understanding teacher motivation and expectancy theory was one of them.

Expectancy theory suggests a relationship between effort and performance, performance and reward, and reward and personal aim (Shah \& Shah, 2008). Nadler and Lawler (as cited in Mowday \& Nam, 1997) show in a figure the sequence of motivation and behavior found in expectancy theory: "Motivation $\rightarrow$ Effort [a person's ability begins to take effect] $\rightarrow$ Performance $\rightarrow$ [hopefully] Outcomes (rewards)" (p. 69). Namely, when a person is motivated to do something, he/she puts some effort into performing the task. The person's ability to perform the task combines with his/her effort. Then, the person performs the task, and hopefully, he/she obtains positive outcomes. However, as the authors indicate, the outcomes which derive from the environment (extrinsic) or the individual himself/herself (intrinsic) may be negative.

\subsection{ESL/EFL teachers' motivation}

About ESL/EFL teachers' motivation research, not much has been found. The reason may be that for about thirty years researchers focused on students' motivation since they thought it was the only prerequisite for language success. This came as a result of the theory of motivation introduced by Gardner and Lambert in 1959 which classified students' motivation into integrative and instrumental. In the 1990s, when researchers realized that there had been much interest in students' motivation but none in teachers' motivation, and it appeared that teachers' motivation had a major impact on students' motivation, researchers began to investigate teachers' motivation. Dörnyei (2001) has confirmed the importance of teacher's motivation: “...the teacher's level of enthusiasm and commitment is one of the most important factors that affects the learners' motivation to learn" (p. 156).

In the literature, few studies on factors that motivate ESL/EFL teachers have been found. Pennington appears to be the pioneer in this line of research. Her article (1991) is not on teachers' motivation but it is related. She states that work satisfaction is influenced by factors inside and outside the work environment. She also says that ESL teachers are satisfied with their work but dissatisfied with "pay, promotions and administrative aspects" (p. 59). Professional recognition probably guarantees work satisfaction. In a second article, Pennington (1992) applies Hackman's characteristics model of work motivation to English language teaching. His model focuses on internal rewards resulting from the job. Pennington recommends that his principles for job design be used when designing programs, so that teachers' motivation will increase, teachers will become more committed to their job, and their performance will improve.

A few other studies were published afterwards. Kyriacou and Kobori (1998) report on student teachers' motivation to become EFL teachers. Their motives include enjoyment for the English language, importance of English to the student teacher, and willingness to help children. Moreover, Tziava's (2003) dissertation reports on Greek EFL teachers' motivation and demotivation. Her findings show that what motivates Greek teachers the most is working with young students whereas what demotivates them the most is their pay. Furthermore, Johnson (2001) analyzes Mexican EFL teachers' motivating and demotivating factors, such as curriculum, institution, and classroom. What Johnson finds is that being a part of curriculum development, transmitting knowledge to students, getting trained, and having supportive colleagues are factors that motivate teachers. Also, in a study conducted in Spain, Bernaus, Wilson, and Gardner (2009) report on student motivation and success, and the relationship between teacher motivation and class strategies. What they find suggests that "teacher motivation is related to teacher use of motivating strategies, which in turn are related to student motivation and English Achievement" (p. 25).

Despite results found in studies conducted on ESL/EFL teachers' motivation to date, much still needs to be done. In the present study, the researcher questions whether factors other than pay, promotion, recognition, 
administration, curriculum, classroom, working conditions, training and colleagues--factors found by researchers on studies done on ESL/EFL teachers' motivation--motivate the Turkish ESL/EFL teachers who have participated in the present study.

\section{Method}

\subsection{Participants}

Eight teachers from Eskisehir Osmangazi University Preparatory English Program, four males and four females, participated in the study. One teacher volunteered to be interviewed and suggested that one of her colleagues be interviewed. The second teacher recommended a third teacher, and so forth. Accordingly, snowball selection was used since the researcher did not know most of the teachers. "Snowball sampling consists of identifying respondents who are then used to refer researchers on to other respondents" (Atkinson \& Flint, 2001, para. 1).

About their age and experience as EFL teachers, the youngest teacher was 26 and the oldest was 37 years old. The mean age of male teachers was 29.5 years and that of female teachers was 31.5 years. The mean years of employment in EFL teaching was 6.5 years for male teachers and 8.5 years for female teachers. The reason the teachers from the Program were chosen to participate in the study was that some teachers had confided in the researcher about their frustrations and disappointment working in the program. Since the researcher had been the founder of the program, although not a part of the program any longer, she felt that she needed to find out what motivated the teachers and offer suggestions that would enhance the teachers' motivation.

\subsection{Data Collection}

To understand the reasons that some of the teachers working at the Preparatory English Program lacked motivation, the researcher has done a case study of eight teachers. Becker (as cited in Merriam, 1988) affirms that the goal of a case study is to understand those being studied and "to develop general theoretical statements about regularities in social structure and process" (p. 11). Merriam (1988) explains, [It] "can be defined as an intensive, holistic description and analysis of a single entity, phenomenon, or social unit" (p. 16). To collect data, unstructured interviews were used. "Unstructured interview is the mode of choice when the interviewer does not know what he or she doesn't know and must therefore rely on the respondent to tell him or her" (Lincoln \& Guba, 1985, p. 269). That explains why the researcher has chosen unstructured interviews to collect data.

Thus, after receiving permission from the Chair to interview eight teachers, the researcher began the data collection. At the beginning of the interviews, the researcher informed the teachers about the purpose of the study and assured them that the information provided would be kept confidential. Nevertheless, the results would be shared with them and the administrators. After some small talk, the researcher started the interviews by asking the teachers to talk about their motivation and what they thought should be done to enhance it. The interviews took place both in the teachers' workplace and in the researcher's office. Some interviews lasted one hour; some, two hours. Some teachers were interviewed only once and some others, twice. Four teachers were interviewed individually; four others, in pairs, according to their preferences. Most teachers were very articulate; therefore, it was not necessary to remind them of the purpose of the interviews. As the researcher expected, most teachers were anxious to share their feelings about the topic. The teachers hoped that the results of the study would be used to enhance their motivation and motivate those who lacked motivation.

\subsection{Data Analysis}

Once all eight teachers were interviewed, the data were organized and coded to answer two research questions: 

A. What motivates Turkish EFL teachers working at a Preparatory English Program of a university in Turkey?

B. How can the Turkish teachers' motivation be enhanced?

Themes related to motivation and demotivation emerged, and were categorized into intrinsic (individual) and extrinsic (environmental) motives, as explained by Nadler and Lawler (as cited in Mowday \& Nam, 1997) when discussing expectancy theory.

\section{Findings and Discussion}

To answer the first research question--What motivates Turkish EFL teachers working at a Preparatory English Program of a university in Turkey?--the researcher has compiled a list of intrinsic factors (Table 1) that motivated the teachers:

\section{Table 1}

Intrinsic factors that motivated teachers

\begin{tabular}{lc}
\hline \multicolumn{1}{c}{ Intrinsic motivation } & Frequency \\
\hline Wanting to become a teacher & 6 \\
Being born to be a teacher & 2 \\
Being curious about the teaching profession & 1 \\
Being knowledgeable & 1 \\
Having experience & 1 \\
Being able to motivate myself & 1 \\
Knowing how to work with people & 1 \\
\hline
\end{tabular}

Table 1 lists the factors that the teachers considered their source of intrinsic motivation. As Table 1 shows, six out of eight teachers said that they had chosen to be teachers. For example, a 31-year-old male teacher with nine years of experience as an EFL teacher affirmed that a teacher's career was a very important one; therefore, he wanted to become a teacher. Moreover, a 28-year-old female teacher with eight years of experience said that while still in high school she decided to become an EFL teacher. Another female teacher, a 31-year-old with nine years of experience, said that she always wanted to be a teacher and even if she could retire soon, she would not. Also, two of the teachers who said they wanted to become teachers said later that they were born to teach. In addition, a 31-year-old male teacher with nine years experience stated that he was "curious about the teaching profession" and that was the reason he decided to become a teacher. In an interview for ELT News: Teaching English in Japan - David Nunan (2003), Nunan had this to say about his motivation as a teacher: "I love what I do, and when you love what you do, then you are automatically motivated" (para. 2). Thus, when some of the teachers stated that they wanted to become teachers or they were born to teach, it probably meant that they were "automatically motivated", too.

In reference to being knowledgeable and having experience, knowledge comes with experience, but it does not mean that lack of experience means lack of knowledge. The youngest female teacher (28 years old) who had been teaching for only four years was one of the most motivated teachers. She had already completed her master's degree at one of the top universities offering master's degree in English Language Teaching (ELT) in Turkey. She sounded very knowledgeable and eager to continue learning but frustrated because some teachers lacked motivation:

I like to talk [to the teachers] about new things related to our profession, things I read in journals. . . . Sharing is the key to motivation. However, some teachers don't want to share or listen to those who are willing to share. I fear they think I'm showing off. I feel frustrated, annoyed. I expected teachers here to want to learn. The lazy ones say, "You shouldn't do that", that is, trying to share what you know with older teachers. These teachers are not open to new ideas. Their response is always the same, "I'm experienced". Every teacher should be open to 
Erkaya, O. R.

new ideas. I guess I have to be patient with the lazy older ones.

The quotation above explains how crucial support from colleagues is for teachers to be motivated to keep on learning. The findings support Johnson's (2001). She affirmed that the support teachers received from colleagues was one of the factors that motivated them. Moreover, the teachers who stated that they wanted to be a part of the teaching profession and were born to teach should probably have said that they could motivate themselves. Nevertheless, only the 31-year-old teacher with eight years of experience, said: “...I enjoy coming to work. The reason is that I can motivate myself. My motivation can be described as intrinsic motivation. Well, what can I say? I was born to teach". The findings support Doyle and Kim's (1999). The teachers in their study were also intrinsically motivated.

The last intrinsic factor that motivated one of the teachers was "knowing how to work with people" which was mentioned by a 30-year-old female teacher who had been working as a teacher for nine years:

In the previous university I worked at, there were too many teachers, so there was too much gossip going on. Gossip, in my opinion, is due to lack of things to do, lack of interests, lack of hobbies. In fact, gossip is a hobby to many people. Usually older instructors like to gossip. The solution to this problem is to keep these teachers in constant training, to keep them busy, active all the time. But, I know how to handle these teachers; I know how to work with people.

Again, based on Johnson's (2001) result, having supportive colleagues was a source of motivation. Yet, to get support from colleagues a teacher must support them, too, and what a teacher who took part in Johnson's research said about her source of motivation was having "team work attitude" (p. 11).

Although several intrinsic factors motivated many teachers who participated in the current study, few extrinsic factors motivated them. Table 2 lists the extrinsic factors:

Table 2

Extrinsic factors that motivated teachers

\begin{tabular}{lc}
\multicolumn{1}{c}{ Extrinsic motivation } & Frequency \\
\hline Working with students & 3 \\
Teaching at a university & 2 \\
Having good instructional materials & 1 \\
\hline
\end{tabular}

When a person decides that he/she wants to become a teacher, the person knows that he/she will be working with students. Thus, it is no surprise to find that students were the most motivating extrinsic factor. A 27-year-old male teacher with four years of experience stated: "I like teaching because students motivate me. When my students learn what I teach, I get motivated". Additionally, a 37-year-old female teacher with thirteen years of experience who appeared to be the most demotivated teacher made some comments about the students she taught in her previous job: "In my first job as a teacher at a private language school, when I saw that my students' reacted positively when learning something I taught, I felt motivated. Also, even my students' attendance motivated me". What the teacher said supported what one teacher said in Johnson's study (2001): "see learning [underlined by the writer] taking place/when they understand" (p. 7).

Teaching at a university was the second extrinsic factor mentioned and one that motivated a 27-year-old male teacher with four years of experience. What caused him to make such a statement was that he had previously taught EFL in a high school:

I am motivated to work at the university because I have more responsibility teaching at the university than I had in high school. In high school, there was more administrative work. Also, here no one evaluates me. I feel free to do what I want in my class.

According to Hackman (as cited in Dörnyei, 2001), teachers are more motivated to do their job when the job 
gives them "autonomy (i.e. the worker is given control of what, how, and when the work is done)..." (p. 160). Dörnyei calls teachers' autonomy an open "career path" (p. 162). As far as instructional materials are concerned, the last extrinsic factor that motivated some teachers, a 31-year-old female teacher with eight years of experience said that among several factors that motivated her, instructional materials were one of them. Among the factors that influenced teachers, Freeman and Freeman (1994) listed availability of materials, too.

To answer the second research question -- How can the Turkish teachers' motivation be enhanced? - a list of factors related to extrinsic motives, was compiled (See Table 3). The list has been classified into five groups: working conditions, colleagues, classes, administrators, and students. These extrinsic factors would enhance the teachers' motivation. Without them, the teachers felt somehow demotivated:

Table 3

Extrinsic factors that would enhance teachers' motivation

\begin{tabular}{lc}
\hline \multicolumn{1}{c}{ Extrinsic motivation } & Frequency \\
\hline \multicolumn{1}{c}{ Colleagues } & 4 \\
Hearing less gossip & 3 \\
Getting support/guidance/feedback from colleagues and an ELT specialist & 2 \\
Having motivated colleagues & 1 \\
Getting rid of demotivated teachers & 1 \\
Working together with all teachers & 1 \\
Having more informed teachers about program and students & Working conditions \\
Moving to the main campus & 6 \\
Having fast Internet connection on campus & 2 \\
Knowing that administrators know teachers' interests/preferences & 2 \\
Having major responsibilities such as being one of the administrators & 2 \\
Getting involved in planning & 1 \\
Reducing the gap between administrators and teachers & 1 \\
Having well-organized meetings: agenda beforehand and teachers' attendance & Classes \\
Teaching fewer classes & Pay/Benefits \\
Receiving higher pay & 3 \\
Getting benefits such as free time & Students \\
Having motivated students & 2 \\
\hline
\end{tabular}

In the first group, colleagues, the teachers listed seven factors that would greatly enhance their motivation, and the reduction of gossip was on top of the list. The 31-year-old male with nine years of experience affirmed: "Gossip is a serious problem with the administration". Two male teachers, the 34-year-old and 27-year-old, agreed on what to do to lessen the problem: "If teachers have more things to do, there will be less gossip". And, "Only male teachers should teach here instead of female teachers. Female teachers gossip too much. Gossip has a negative effect on one's motivation". In addition, the 30-year-old teacher with nine years of experience was the only female who pointed out that gossip was a problem. She explained not only why but also what to do about it: "Gossip is due to lack of things to do, lack of interests, hobbies. Gossip is a hobby to some teachers. Older teachers like to gossip. The solution is to train them, to keep them busy, active". Gossip has not been cited in the related literature. The current study supported Johnson's (2001) findings in terms of training: "lots of teaching training" (p. 10) as a source of motivation.

Getting support/guidance/feedback from colleagues and a specialist in ELT was the second factor in colleagues that would increase the teachers' motivation. The 31-year-old male teacher who had been an EFL teacher for nine years already said: "I get no support from anyone at work. There is no one to guide us. Nobody takes time to know what we need. We need someone in ELT to guide us". If he needed guidance, what would 
less experienced teachers say? The 28-year-old female teacher who was less experienced (four years of experience) affirmed: "They should hire a native speaker or someone in the same area should be in charge of the Department". It is essential to point out that except for the two years that the researcher was the director of the program when the program opened its doors, there has never been a director who was a specialist in ELT. All those chairing the Department since then have been professors from the Electrical/Electronics Engineering, Mechanical Engineering, and Chemistry Departments. Fortunately, the assistants to the chair have always been chosen from among the most experienced and highly educated teachers. The present study supported Johnson's (2001) results. Two teachers in Johnson's study were demotivated because of the supervisor's behavior: "supervisor who gives you a book at the beginning of the year and that's all/provides no guidance... [and] not having full support in disciplinary methods" (p. 11). Also, a teacher in Su's (2012) study talked about her unhappiness working as an assistant teacher because of the lack of support from the class teacher: “...Never sharing any teaching technique with me nor paying attention to how I did my teaching... He didn't give me any support... and that environment made me uncomfortable" (p. 13).

The teachers in the current study needed not only support and guidance but also feedback from at least colleagues. The oldest and most experienced female teacher affirmed: "I'd love to get feedback about my work". Even with nine years of experience, she thought feedback was essential. Lathan et al. (as cited in Dörnyei, 2001, p. 159) emphasized the importance of "performance feedback". Additionally, Johnson (2001) added that "getting constructive feed-back" (p. 11) motivated the teachers in her study.

The next two factors in colleagues--having motivated colleagues and getting rid of demotivated teachers--would motivate some of the teachers. Having motivated colleagues was a statement made by the 30-year-old female teacher who appeared to be the most motivated teacher. Maybe she wanted all teachers to be as motivated as she was. On the other hand, the oldest teacher (37 years old) thought that to enhance her motivation, the administrators should "get rid of demotivated teachers". The 31-year-old female teacher did not share the same opinion with the 37-year-old female teacher. She believed that it was imperative that the administrators and motivated teachers motivated those who lacked motivation. Perhaps, the reason was based on what the 28-year-old female teacher emphasized: "Demotivated teachers see only the negative aspects of the job and that is bad for the motivation of all teachers". The results supported Pennington's (1995) findings. Pennington said that when teachers were intrinsically motivated, they did not put emphasis on negative extrinsic factors. The 30-year-old female teacher explained: "Some teachers have no motivation. They know they will not lose their job [no negative outcome] and they will get paid at the end of the month [expected outcome]. There is no increase in pay [no positive outcome] when a teacher tries hard [puts effort into teaching]". The teacher was referring to older teachers. What expectancy theory emphasizes is that motivation leads to effort which encourages performance (combined with ability, skills) which results in positive or negative outcomes. Based on the teacher's statement, the demotivated teachers had neither positive nor negative expectations.

Additionally, working together with all teachers (in the group colleagues) would also increase the teachers' motivation, according to the 37-year-old female teacher. Nonetheless, she knew what the teachers could do to enhance their own motivation. She thought it was important for teachers "to work together", and when and if they had problems, they should "work things out". Tziava's findings (2003) also agreed that a good relationship with colleagues motivated teachers and so did Johnson's (2001). More specifically, the teachers in Johnson's study affirmed that "good, friendly work environment [italicized by the author] ...professional atmosphere, team work attitude" motivated them. However, the "apathetic" (p. 11) behavior of some teachers demotivated them. Having informed teachers about program and students was the last factor in colleagues. The 37-year-old female teacher thought that if all teachers were more informed not only about the program but also about students, teachers' level of motivation would increase. This, according to Johnson's (2001) study, related to "professional atmosphere" (p. 11), a factor that motivated the teachers in her study.

In the second group, working conditions, the teachers cited two factors. Moving to the main campus was the first factor that would increase the teachers' motivation. The oldest (37 years old with 13 years of experience) 
female teacher's frustration was in reference to the location of the campus. Five other teachers also said that moving to the main campus would enhance their motivation. "They should move the program to the main campus. Students need to feel they belong to the university. I feel the same. I'm a faculty member of a university, not of a dersahane [language school]", said the oldest female teacher. Additionally, the 26-year-old male teacher with two years of experience stated that the reason he would like to move to the main campus was that clubs were on the main campus. Also, teaching on both campuses meant going from one campus to the other one often and that was "time consuming", "loss of energy", and "extra money for transportation". Another male teacher, the 31-year-old with nine years of experience, had similar complaints: "time consuming and problems with transportation". Also, the 28-year-old female teacher with four years experience affirmed that her campus was "isolated from the main campus". And, the last comment about wanting to move to the main campus was made by the 32-year-old female teacher with nine years of experience: "too tiring going from one campus to the other to teach classes". The teachers were right saying that the main campus was a better place for both students and faculty members. The Preparatory English Program is located on a very small campus with only one old building. In contrast, the main campus, a large new campus, has many facilities such as a large library, several restaurants and cafeterias, a sports complex, etc. Also, clubs such as the theater club, the literature club, etc. available to students and faculty are on the main campus. Johnson's (2001) comment about the teachers in her study was that pleasant physical space was a source of motivation.

Having fast Internet connection on campus was the second factor in working conditions that would increase some teachers' motivation. The 28-year-old female teacher with four years of experience who had just completed her master's degree at a private university that had fast Internet connection thought that it would help her to research her area of interest. Additionally, the 37-year-old female teacher thought Internet would boost teachers' motivation. The relationship between the Internet and teachers' motivation was also found in Johnson's (2001) study: "access to: computers... email..." (p. 10) increased teachers' motivation.

In the group administration, one factor that would greatly increase the teachers' motivation was their knowing that the administrators were aware of teachers' interests, preferences, likes, dislikes, etc. Although only two teachers commented on that, their statements revealed multifaceted needs, needs that would enhance their motivation. The oldest male teacher, the 34-year-old who had been teaching EFL for eleven years and appeared to be the most demotivated male teacher, said that it was imperative that the administrators "knew the likes, dislikes, and interests of teachers to determine who to send where, for example, to conferences abroad". In addition, the 30-year-old female teacher with nine years of experience insisted:

To enhance teachers' motivation, the administrators should observe all teachers. They should find out what they do in their free time; they should get to know them as instructors and people; they should know the differences among teachers, that is, their likes and dislikes. They should ask their opinion about what happens here at school. They should be open to all teachers. They should ask them things like, "Can you do this? Would you like to do it?" They should see teachers as individuals. People are different. They should show they care for the teachers. They should provide opportunity for an open dialogue between them and the teachers, and among the teachers. They should help motivate teachers, like "I motivate you; you motivate someone else; and so on”. They should plan events, trips to provide opportunities for teachers to get together.

Pennington (1991) found that lack of support from the administration was a source of demotivation and support perhaps resulted from knowing the teachers.

Furthermore, two teachers believed that having major responsibilities such as being one of the administrators would help to enhance their motivation. The 37-year-old female teacher stated: "Being a part of the administration would motivate me. I'd be a part of a team. Getting involved in planning like the administrators would motivate me. I don't like to feel like an outsider. I like to have responsibilities". About having major responsibilities, the 30-year-old female teacher confirmed what the previous teacher said: 
"Promotion ... major responsibilities would motivate me and other teachers". Herzberg's management theory (as cited in Pennington, 1992) suggests that to improve workers' motivation, "jobs can be enriched or redesigned to increase the level of such features as... responsibility...” (p. 203).

What becomes apparent in the present study is that for a teacher to have major responsibilities, he/she would have to be a part of the administration. Without responsibilities, a teacher would "feel like an outsider", as the 37-year-old female teacher said. As the researcher understood, two groups of people work in the Preparatory English Program: One consists of teachers who primarily teach and one consists of administrators who are the chair and assistant chair, and few teachers who also help administering the program. As a result, the next factor -Reducing the gap between the administrators and the teachers -- a statement made by the oldest female teacher referred to the teachers who primarily taught. Only the administrators could assign class load, develop the program, choose textbooks, etc. The teachers not involved in administrative work had to accept the decisions made by the administrators. The older female teacher affirmed, "I'm a robot: the schedule is here; the book is here. We the administrators make the choices". The teachers who were not a part of the administrative group were not very informed about the program and students, and did not help with planning--two other factors that would enhance the teachers' motivation and were also mentioned by the same teacher. This teacher also insisted that their meetings were not well organized, and "having well-organized meetings: agenda beforehand and teachers' attendance", would enhance the teachers' motivation. A good relationship between administrators and teachers, a factor that motivated teachers, was found in Tziava's study (2003). Moreover, "support and respect [italicized by the author] by the coordinator" (p. 11) motivated many teachers who were a part of Johnson's (2001) study.

In the group classes, the only factor that the teachers brought up was teaching fewer classes. Only three experienced and not so experienced teachers wanted to teach fewer classes. To understand about their class load, it is vital to explain that teachers in the program must teach a minimum of 12 hours a week. If they teach more than 12 hours, they get extra pay. Some teachers choose to teach many hours, but some prefer to teach the minimum. The administrators decide on the teaching load. Thus, if the administrators assign some teachers more hours than they want to teach, the teachers feel demotivated. The reasons that some teachers prefer to teach the minimum load is that according to the 31-year-old male teacher with nine years of experience, "Fewer classes would be more motivating; I'd have more time to concentrate on my job. Many classes a week is tiring, too much distraction". Additionally, the 28-year-old female teacher with four years of experience insisted: "I have to agree that more teaching means more learning, but less time to do research for myself, for my classes". Also, the 30-year-old female with nine years who appeared to be the most motivated teacher said: "I must teach too many classes. It's too tiring. Besides, the Preparatory English Program, I teach English in other Departments". Being married with a small daughter may explain the reason that this teacher did not want to teach too many extra hours a week. This also supports what one of the teachers in Johnson's (2001) study stated about being demotivated: "overwork".

In the group pay/benefits, two factors were cited: receiving higher pay and getting benefits, such as free time. Receiving higher pay would improve the motivation of two teachers. This is no surprise since Turkish teachers do not receive high salaries. Even so, most of the teachers interviewed did not complain about their pay. The teacher who complained about the salary was the 34-year-old male teacher who believed his pay was "low" and he would "be more motivated with more pay". Also, he said that "part-time jobs would help to increase" his monthly pay, but those working for the government were not allowed to have part-time jobs. This male teacher was married to a teacher who also worked in the program. With two children to support and two low pay checks, no wonder he was demotivated. Furthermore, the low salary prevented teachers from "paying conference fees", as the 31-year-old female teacher stated. Again, the findings in the present study supported Pennington's (1991) who found that ESL teachers were dissatisfied with their pay. Tziava's (2003) results, in contrast, found pay to be the most demotivating factor.

Getting benefits such as free time was the next factor in the group Pay/Benefits. It did not seem to be a 
major concern to most teachers since only one teacher wanted "more free time". The statement was made by the most motivated teacher, the 30-year-old female. The reason was probably that at the time of the interview she taught not only in the Preparatory English Program but also in other departments on the main campus. She had to go from one campus to the other one by bus. Moreover, she was married with a five-year-old daughter and had like all other teachers to be at work from 9 a.m. to 5 p.m. To a certain extent, Johnson's (2001) findings were supported by those in the present study. Johnson found that some teachers were demotivated because "classes [were] spread throughout the entire day with no break" (p. 10).

In the group students, having motivated students was a factor that would increase the 30-year-old female teacher's motivation in spite of her being very motivated. She believed that demotivated students did not motivate teachers. Also, the 31-year-old female teacher affirmed: "Demotivated students demotivate teachers". Jesus and Lens (2005) believed, “. . . while teacher motivation is fundamental to the teaching/learning process, many teachers are not highly motivated" (p. 120). Dörnyei (2001) concurred that if teachers were motivated to do their job, their students would be motivated to do theirs, too. However, two teachers who participated in the current study expected their students to motivate them. The findings supported Johnson's (2001). Johnson's findings revealed the following about teachers' demotivation: "apathetic students who don't care if they learn" (underlined by the author) and "negative attitude/lack of interest/unmotivated students" (p. 8).

\section{Limitations}

The current study focused on the motivation of eight teachers working at Eskisehir Osmangazi University Preparatory English Program and ways to increase their motivation. The number of participants was small; consequently, the study was limited in scope. At the time that the teachers were interviewed, the program consisted of thirty-nine teachers, but only eight teachers volunteered to participate in the study. Because of that, the findings cannot be generalized to other EFL teachers working in Turkey. Also, the teachers represented only one group of EFL teachers in Turkey. There are several other groups: elementary, high, and senior high school teachers; university teachers; and language school teachers. Also, the study included only teachers who had from four to thirteen years of experience. The results might have been different had teachers working with students from a variety of schools and those with fewer or more years of experience been included. What is more, each teacher was interviewed once or twice. Had they been interviewed several times, the researcher might have collected more and different data.

\section{Conclusion and Implications for Research}

The purpose of the present study was to find out what motivated eight teachers working at Eskisehir Osmangazi University Preparatory English Program and how their motivation could be enhanced. After analyzing the data, the researcher concluded that the teachers were more intrinsically than extrinsically motivated, and what they explained as enhancing their motivation was classified into six groups: working conditions, colleagues, classes, pay/benefits, administration, and students. Looking at the findings, the researcher understood that what would increase the teachers' motivation the most would be their colleagues; that is to say, what they needed was supportive colleagues, colleagues that would be there for them when they needed them, that would guide them if they needed guidance, that would work with them when and if necessary. Moving to the main campus (working conditions) would also boost their motivation. The administrators would also play an important role in the teachers' motivation if they were more open to the teachers, if they tried to understand them better, and if they made them a part of the group of administrators, that is to say, if they gave all teachers more responsibilities.

The results of this study have yielded quite a few implications for future research. The researcher would like to see similar studies having as participants not only Turkish teachers who teach EFL in preparatory English programs, but also those who work with students from k-12, and at public and private universities. Those would help to give a better idea of Turkish EFL teachers' motivation. Additionally, it would be interesting if surveys 
were conducted with different groups of teachers to find out what motivated them and how their motivation could be enhanced because with a survey teachers would not have to think much about what to say but choose what was true to them. Replicating the same study using EFL teachers working in Preparatory English programs in different parts of Turkey to understand whether the results would be similar would be significant. The researcher concluded that this was just the beginning of many more studies to be conducted in the same area. This study revealed facts that the teachers who took part in the study may not even know. The results may help the teachers to be more responsible for their own and the motivation of those who work with them.

\section{References:}

Atkinson, R., \& Flint, J. (2001). Accessing hidden and hard-to-reach populations: Snowball research strategies. Social Research Update, 33. Retrieved May 15, 2012, from http://www.soc.surrey.ac.uk/sru/SRU33.html

Bernaus, M., Wilson, A., \& Gardner, R. C. (2009). Teachers' motivation, classroom strategy use, students' motivation and second language achievement. Porta Linguarum, 12, 25-36.

Bishay, A. (1996). Teacher motivation and job satisfaction: A study employing the experience sampling method. Journal of Undergraduate Sciences, 3, 147-154.

Czubaj, C. A. (1996). Maintaining teacher motivation. Education, 116(3), 372-378.

Dörnyei, Z. (2001). Teaching and Researching Motivation. Harlow, England: Longman.

Dörnyei, Z. (2003). Attitudes, orientations, and motivations in language learning: Advances in theory, research, and applications. Language Learning, 53(1), 3-31. <http://dx.doi.org/10.1111/1467-9922.53222>

Doyle, T., \& Kim, Y. M. (1999). Teacher motivation and satisfaction in the United States and Korea. MEXTESOL Journal, 23, 35-48.

Freeman, D., \& Freeman, Y. (1994). Between worlds: Access to second language acquisition. Portsmouth, NH: Heinemann.

Gardner, R. C., \& Lambert, W. E. (1959). Motivational variables in second language acquisition. Canadian Journal of Psychology, 13, 266-272. <http://dx.doi.org/10.1037/h0083787>

Jacques, S. R. (2001). Preferences for instructional activities and motivation: A comparison of student and teacher perspectives. In Z. Dörnyei, \& R. Schmidt (Eds.). Motivation and second language learning (pp. 187-214). Honolulu, HI: University of Hawaii Press.

Jesus, S. N., \& Lens, W. (2005). An integrated model for the study of teacher motivation. Applied Psychology: An International Review, 54(1), 119-134. <http://dx.doi.org/10.1111/j.1464-0597.2005.00199.x>

Johnson, C. R. (2001). Factors influencing the motivation and de-motivation in Mexican EFL teachers. MEXTESOL Journal. ERIC Document Reproduction Service No. 459605.

Johnson, S. M. (1986). Incentives for teachers: What motivates, what matters. Educational Administration Quarterly, 22(3), 54-79. <http://dx.doi.org/10.1177/0013161X86022003003>

Kassabgy, O., Boraie, D., \& Schmidt, R. (2001). Values, rewards, and job satisfaction in ESL/EFL. In Z. Dörnyei $\&$ R. Schmidt (Eds.). Motivation and second language learning (pp. 213-237). Honolulu, HI: University of Hawaii Press.

Kyriacou, C., \& Kobori, M. (1998). Motivation to learn and teach English in Slovenia. Educational Studies, 24(3), 345-351. <http://dx.doi.org/10.1080/0305569980240307>

Lincoln, Y. S., \& Guba, E. G. (1985). Naturalistic inquiry. Beverly Hills, California: Sage Publications.

Lumsden, L. (1998, March). Teacher morale. Clearinghouse on Educational Policy and Management. ERIC Digest 120. Retrieved May 15, 2012, from http://eric.uoregon.edu/publications/digests/digest120.html

Merriam, S. B. (1988). Case study research in education: A aualitative approach. San Francisco, California: Jossey-Bass Publishers.

Mowday, R. T., \& Nam, S. H. (1997). Expectancy approaches to faculty motivation. In J. L. Bess (Ed.), Teaching well and liking it: Motivating faculty to teach effectively (pp. 110-124). Baltimore: Johns Hopkins University Press.

On teaching. (2003). ELT news: Interview with David Nunan. Retrieved May 15, 2012, from 
http://www.eltnews.com/features/interviews/001_david_nunan1.shtml

Pennington, M. C. (1991). Work satisfaction and the ESL profession. Language, Culture and Curriculum, 4(1), 59-86. <http://dx.doi.org/10.1080/07908319109525094>

Pennington, M. C. (1992). Motivating English language teachers through job enrichment. Language, Culture and Curriculum, 5, 199-218. <http://dx.doi.org/10.1080/07908319209525126>

Pennington, M. C. (1995). Work satisfaction, motivation and commitment in teaching English as a second language. New York: ERIC Clearing house. (ERIC No. ED404850)

Pennington, M. C., \& Ho, B. (1995). Do ESL educators suffer from burnout? Prospect, 10, 41-53.

Pinto, G., \& Pulido, E. (1997). Motivation of faculty members at a Latin American university: A case study. European Journal of Engineering Education, 22(4), 421-426. $<$ http://dx.doi.org/10.1080/03043799708923473>

Scott, C., \& Dinham, S. (1999). The occupational motivation, satisfaction and health of English school teachers. Educational Psychology, 19(3), 287-303. <http://dx.doi.org/10.1080/0144341990190304>

Scott, C., Cox, S., \& Dinham, S. (1999). An English study of teacher satisfaction, motivation, and health. AERA, 1(5), Stress and Coping Home Page. Retrieved May 15, 2012, from http://www.gsu.edu/ wwwsce/scIss_April_00.html

Shah, K., \& Shah, P. J. (2008). Theories of motivation. Laynetworks. Retrieved May 15, 2012, from http://www.laynetworks.com/Theories-of-Motivation.html

$\mathrm{Su}, \mathrm{Y}$. N. (2012). Teach to live or live to teach: A case study on the educational beliefs of displaced teachers in Taiwan. International Journal of Research Studies in Education, 1(1), 3-20. $<$ http://dx.doi.org/10.5861/ijrse.2012.v1i1.3>

Tziava, K. (2003). Factors that motivate and demotivate Greek EFL teachers. Unpublished doctoral dissertation. The University of Edinburgh, Edinburgh.

What makes teachers tick? (2002). A policy research report on teachers' motivation in developing countries. London: VSO. Retrieved June 27, 2012, from http://www.vso.org.uk/Images/What_Makes_Teachers_Tick_tcm79-21000.pdf 
Erkaya, O. R. 